\title{
Effect of Nigella sativa Oil on the Imidacloprid Induced Toxicity in Male Albino Mice
}

\author{
Reda K., Abdel-Razik \\ Mammalian Toxicology Dept, Central Agricultural Pesticide Lab, Agricultural Research Center, Alex. Egypt \\ Email: sanarach69@gmail.com
}

\begin{abstract}
Imidacloprid (IMC) is a systemic insecticide being the most frequently detected neonicotinoid in fruits and vegetables. So, this study was carried out to evaluate the biochemical and the histological alterations associated with IMC toxicity in male albino mice (Muss musculus). Also, the role of Nigella Sativa oil (NS oil), $(4 \mathrm{ml} / \mathrm{kg} \mathrm{bw})$ on the adverse effect of IMC was investigated. The animals were orally administered with $1 / 50 \mathrm{LD}_{50} \mathrm{IMC}(2.6 \mathrm{mg} / \mathrm{kg} \mathrm{bw})$ for 28 days (5 doses/week). Hepatic and pancreatic toxicity was monitored by quantitative measurements of the serum aspartate aminotransferase (AST), alanine aminotransferase (ALT), $\alpha$ - amylase activities, glucose, total cholesterol, triglyceride, and high-density lipoprotein (HDL) cholesterol levels. Creatinine and urea levels were used as the biomarkers of kidney damages. The results showed that imidacloprid administration caused a significant increase in the body and the organs weights. Also, the ALT Activity, glucose, urea, creatinine, total cholesterol, triglyceride, and HDL cholesterol levels were increased. Whereas the AST and $\alpha$ - amylase activity showed significant reduction when compared with the control group. The effect of IMC on the previous parameters was confirmed by the histological changes of liver and kidney. In addition, NS oil supplementation showed a significant reduction of IMC adverse effect. This result indicated that imidacloprid has the ability to damage liver and kidney functions and cause histological lesions in mice at the tested sublethal dose. In addition, NS oil supplementation attenuated the IMC adverse effect which confirms its protective influence.
\end{abstract}

Key words: Imidacloprid; Biochemical Studies; Histopathological Examination; Hepatotoxicity; Nephrotoxicity; Nigella sativa; Lipid profile.

\section{INTRODUCTION}

Imidacloprid is a potent neurotoxic insecticide that acts as agonists on the nicotinic acetylcholine receptors (Tomizawa and Yamamoto, 1993). It was extensively used in agriculture and veterinary medicine (Ware and Whitacre, 2004). Lee Chao and Casida (1997) and Tomizawa et al (2005) mentioned that the IMC characterized by high selective insecticidal activity at low application rate, low soil persistence and apparent safety in humans. Also, it was absorbed rapidly from the gastrointestinal tract and eliminated via urine and feces (Kidd and James, 1991). IMC classified as a moderately hazardous pesticide (Class II) Meister (1995) and WHO (2005).

The liver is an important target organ for the toxicity of drugs and xenobiotics due to its connection with the gastrointestinal tract as well as for the singularity and complexity of its anatomical structure and metabolic functions. It can be considered a target organ of numerous chemicals either in the workplace or at home Arafa et al., (2003), and Piñeiro-Carrero and Piñeiro (2004). The activities of serum AST and ALT have been commonly used in the diagnosis of liver diseases as well as in the detection of tissue damage caused by environmental pollution Palanivelu et al., (2006).

Both aminotransferases are highly concentrated in the liver. AST is also diffusely present in the heart, skeletal muscle, kidneys, brain and red blood cells, while ALT has low concentrations in skeletal muscle and kidneys Wroblewski (1958); an increase in serum ALT levels is, therefore, more specific for liver damage. In the liver, ALT is localized solely in the cellular cytoplasm, whereas AST is both cytosolic ( $20 \%$ of total activity) and mitochondrial ( $80 \%$ of total activity) Rej R (1989). Pesticides may damage liver cells and liver transaminases may be used to monitor liver damage.

Hyperglycemia is a metabolic disorder associated with high blood sugar occurs due to the pancreas does not produce enough insulin or when the body cannot use the insulin effectively Alphaamylase is an enzyme that plays an important role in the digestion of starch and glycogen. Alpha-amylase catalyses the breakdown of polysaccharide into monosaccharide and only monosaccharide form of food can absorb in the stomach. so the determination of glucose level and $\alpha$-amylase activity serve as useful biochemical tools to understand etiology of pesticide-induced hyperglycemia (Powers, 2011, Arumugam, Manjula, Paari, 2013, and Pallavi et al., 2015)

Urea, commonly referred to as blood urea nitrogen (BUN) when measured in the blood, is a product of protein metabolism. The BUN is considered a non-protein nitrogenous (NPN) waste product. Urea accounts for the majority (up to $80 \%-$ $90 \%$ ) of the NPNs excreted by the body. The body's dependency on the renal system to excrete urea makes it a useful analyte to evaluate renal function. Creatinine also, an NPN waste product synthesized in the liver, pancreas, and kidneys from the 
transamination of the amino acids arginine, glycine, and methionine. Creatinine produced from the breakdown of creatine and phosphocreatine, it is freely filtered by the glomerulus, these characteristics make creatinine a useful endogenous marker for creatinine clearance and can also serve as an indicator of renal function Price and Finney (2000).

Lipophilic nature of the majority of pesticides may render them with the ability to interact with the serum and tissue lipids. So, that triglyceride (TG), total cholesterol (TC), low-density lipoprotein (LDL) and very low-density lipoprotein (VLDL) cholesterol levels have been reported to be useful tools for determination of pesticides-induce hyperlipidemia Gupta et al., 1994 and Slotkin et al., (2005).

Blood, being the medium of intercellular transport, it rapidly comes in direct contact with various tissues in the body; therefore, the physiological state of an organism is always reflected in the contents of the blood (Narra, 2017). So, the biochemical parameters can indicate toxicity with great potential for environmental monitoring of health (Narra, 2016). Likewise, histopathological changes in animal tissues is a sensitive and rapid method commonly used to detect the toxic potential and risk assessment of chemicals in the environment (Adams, 2002; Crissman et al., 2004; Mela et al., 2007).

Nigella sativa is an amazing herb with a religious background and commonly grows in Mediterranean coasts and Asia. It contains many active components including nigellicine, nigellimine, nigellidine, alphahederin, thymoquinone, thymohydroquinone, dithymoquinone, thymol, and carvacrol (Randhawa and Alghamdi, 2002 and 2011). Most of the potent activity of Nigella sativa herb associated with its volatile oil and a protein component. Salem, (2005) and Randhawa, (2008) reported that $N$. sativa has a wide spectrum of pharmacological actions which include liver tonics, antidiabetic, antihypertensive, diuretics, digestive, anti-diarrheal, anticancer, immunomodulator, analgesic, antimicrobial, antiinflammatory, spasmolytic and bronchodilator

Due to the increasing application of IMC in agriculture to control insect pests and its likely hazard for consumers by intake of fruits and vegetables with pesticide residues, therefore, this study was planned to investigate the effects of IMC sublethal dose on male albino mice by means of quantitative analysis of some biochemical parameters and histopathological alterations to highlight the potential adverse effects of such environmental contaminants. Also, the protective role of Nigella Sativa oil against imidaclopridinduced toxicity was investigated.

\section{MATERIALS AND METHODS}

\section{Chemicals}

Imidacloprid technical grade $(97 \%)$ was obtained from Zhejiang Rayfull Chemicals Co., China. Nigella Sativa oil was obtained from Egyptian Natural Oils Co., Cairo. All other chemicals were purchased from Sigma - Aldrich Co.

2. Animals

Male albino mice weighing, $30 \pm 3 \mathrm{~g}$ were obtained from the animal house, Faculty of Agriculture, Alexandria University. Animals were housed in groups each of five mice in a stainless still cages and kept under laboratory conditions; $25 \pm^{\circ} \mathrm{C}$, $65-75 \%$ humidity and light $12 \mathrm{~h}$ light/ 12 dark. Animals allowed balanced standard rodent diet and water ad libitum for two weeks before being experimented. All procedures involving animals were performed in accordance with the guidelines of the standard procedures established by OECD guideline (2008).

\section{Experimental design}

The animals were divided into four groups, each five animals and orally treated by gavage with 5 doses /week for 4 weeks as follows:

Group, C: Corn oil (1 ml/kg bw) used as control. Group, NS oil: Nigella Sativa oil $(4 \mathrm{ml} / \mathrm{kg}$ bw). Group, IMC: Imidacloprid in a dose equivalent to $2.6 \mathrm{mg} / \mathrm{kg}$ bw $\left(1 / 50 \mathrm{LD}_{50} ; 130 \mathrm{mg} / \mathrm{kg}\right.$ bw obtained from WHO, 2004). Group, IMC+NS oil: Imidacloprid $\left(1 / 50 \mathrm{LD}_{50}\right)$ plus Nigella Sativa oil (4 $\mathrm{ml} / \mathrm{kg} \mathrm{bw}$ ). The animals were weighed weekly. At the end of the experiment (4 weeks), blood was collected in plane tube for serum preparation. Then liver, pancreas, and kidney were quickly removed and weighed individually. The \% of relative organ weight was calculated (organ weight/body weight) $\mathrm{X} 100$. Liver and kidney were fixed immediately in $10 \%$ buffered formalin for histopathological examination.

\section{Biochemical studies}

The collected, blood allowed to clot for $30 \mathrm{~min}$ at room temperature and centrifuged at 4,000 $\mathrm{g}$ using Sigma $3 \mathrm{~K} 30$ bench centrifuges for $15 \mathrm{~min}$ to separate the serum which stored at $\left(-20^{\circ} \mathrm{C}\right)$ until used for the determination of biochemical parameters by using BioMed diagnostic kits (Germany).

\subsection{Measurement of AST and ALT activity}

The transaminases AST and ALT were measured by the Reitman and Frankel, (1957) method. The generation of hydrazone formed with 2, 4-dinitrophenylhydrazine in both transaminase reactions was measured at $546 \mathrm{~nm}$.

\subsection{Measurement of serum glucose level and $\alpha$ - amylase activity}

Serum glucose was measured by employing Trinder, (1969) enzymatic method, uses glucose 
oxidase to catalyze the oxidation of glucose to hydrogen peroxide and gluconic acid. Hydrogen peroxide, when combine with 4-aminoantipyrine and phenol forms a red quinoneimine dye, having an absorbance maximum at $510 \mathrm{~nm}$. The intensity of the red color is proportional to the amount glucose in the sample

A-amylase activity was measured calorimetrically according to Kurrle-Weitenhiller et al., (1996). A-amylase catalyzes the hydrolysis of the EPS substrate (Ethylidene Protected Substrate) p-nitrophenyl-maltoheptaoside 4, 6-ethylidene blocked (ethylidene-G7PNP) forming 2 ethylidene$\mathrm{G} 5+2$ G2PNP +2 ethylidene-G4+ 2 G3PNP + ethylidene-G3 + G4PNP. The $\alpha$-glucosidase hydrolyses all fragments of G2PNP, G3PNP and G4PNP into p-nitrophenol (PNP) and glucose (G). The increase of absorbance, due to PNP formation, is proportional to the activity $\alpha$-amylase in the examined sample measured at $410 \mathrm{~nm}$.

\subsection{Measurement of serum urea and creatinine concentrations}

urea concentrations were measured by the Fawcett and Scott, (1960) method. Serum urea hydrolyzed by urease to form ammonium and carbonate. In alkaline medium, the ammonium ions react with the salicylate and hydrochloride to form a green colored indophenol (2,2 dicarboxylindophenol). The intensity of the color produced is directly proportional to urea/BUN concentration measured at $578 \mathrm{~nm}$.

Serum creatinine was estimated by Jaffes method (1886). In alkaline medium serum creatinine reacts with picrate to produce an orange color that absorbs light at $492 \mathrm{~nm}$. The increase in the absorbance rate is directly proportional to the concentration of creatinine in the specimen.

\subsection{Measurement of serum triglycerides, total and HDL cholesterol levels}

Serum total and HDL cholesterol levels were measured by Richmond, (1973) and Grove, (1979) methods respectively. Under the action of cholesterol esterase cholesterol esters resolve in free cholesterol and fatty acids, and cholesterol oxidase then converts the cholesterol to $\mathrm{H}_{2} \mathrm{O}_{2}$ and cholest-4en-3 one. In the presence of peroxidase $\mathrm{H}_{2} \mathrm{O}_{2}$ oxidatively couples with 4 aminoantipyrine and phenol to produce a red quinoneimine dye, having an absorbance maximum at $510 \mathrm{~nm}$. The intensity of the red colour is proportional to the total cholesterol in the specimen

Triglycerides levels in serum were measured spectrophotometrically by Fassati and Prencipe, (1982) method. TG was hydrolysed by enzyme lipase into glycerol and free fatty acids and then liberated glycerol convert to glycerol-3- phosphate by glycerol kinase. Glycerol-3-phosphate oxidized by glycerol-3- phosphate oxidase into dihydroxyacetone phosphate and hydrogen peroxide. Finally, the hydrogen peroxide is monitored in the presence of horseradish peroxidase with 3, 5-dichloro-2-hydroxybenzenesulfonic acid/4-aminophenazone as the chromogenic system. The high absorbance of this chromogen was at 500 $\mathrm{nm}$. Low density lipoprotein (LDL) and Very low density lipoprotein (VLDL) cholesterol were calculated according to Friedewald's equation 1972.

\section{Histopathological examination}

Samples of liver and kidney were fixed in $10 \%$ buffered formalin. Then, dehydrated by standard procedures and embedded in paraffin, sections approximately $5 \mu \mathrm{m}$ thick were cut, stained with hematoxylin and eosin (H\&E) stains and examined by light microscope (Drury and Wallington 1980).

\section{Statistical analysis}

All results were expressed as mean \pm standard error (SE). The data was analyzed using one-way analysis of variance (ANOVA) followed by the Student-Newman-Keuls Test. The criterion for statistical significance was set at $p<0.01$. These tests were performed using the computer software CoStat program, version 6.2, 2002.

\section{RESULTS AND DISCUSSION}

\section{Body and organs weight}

It was noticed that there was no mortality occurred in any group of animals during the experimental period (4 weeks). Table (1) IMC treated group showed a significant increase in mice's weight during the experimental period compared to control. The relative liver, pancreas, and kidney weights were markedly increased by $10.2,36.1$ and $10.7 \%$ respectively as a percentage of control (Table 2). The obtained results are in line with those of William et al., (2007), who suggested that excessive weight gain is associated with the environmental pollutants, including pesticides. Simons et al.,(1995) cited that the changes in either absolute or relative organ weight after administration of a chemical or drug is an indication of the toxic effect of that chemical. The present study revealed an increase in relative liver weight in IMC treated mice which could be related to IMC toxic effect, and those are consistent with Eissa and Zidan, (2009).

Liver enlargement could be induced as a result of; 1) the maintenance of the liver normal functional capacity (Robinson and Yarbrough, 1978), 2) the accumulation of abnormal amounts of fat, predominately triglyceride, a result of an imbalance between the rate of synthesis and the rate of release of triglyceride by the parenchymal cells into the systemic circulation (Plaa, 1980), or 3) the increased demands for the detoxification of toxic compounds, (Okuna et al., 1976). In contrast; Bhatnagar and Jain, 1986 stated that the increase in liver weight is not necessarily considered toxic lesions since this effect is observed in a large number of compounds. 
Table 1: Body weight pattern of male albino mice orally administrated with IMC (2.6 mg/kg bw), NS oil $(4 \mathrm{ml} / \mathrm{kg} \mathrm{bw})$ and their combination.

\begin{tabular}{lccccc}
\hline \multirow{2}{*}{ Animal Group } & \multicolumn{5}{c}{ Body weight (gm) / Weeks } \\
\cline { 2 - 6 } & Zero & First & Second & Third & Fourth \\
\hline C & $29.4^{\mathrm{a}} \pm 0.87$ & $31.00^{\mathrm{b}} \pm 0.47$ & $32.4^{\mathrm{b}} \pm 0.96$ & $33.0^{\mathrm{b}} \pm 0.61$ & $34.8^{\mathrm{b}} \pm 0.30$ \\
\hline NS oil & $29.2^{\mathrm{a}} \pm 0.63$ & $29.75^{\mathrm{b}} \pm 0.56$ & $31.4^{\mathrm{b}} \pm 0.96$ & $31.6^{\mathrm{c}} \pm 0.60$ & $33.8^{\mathrm{c}} \pm 0.42$ \\
\hline IMC & $29.4^{\mathrm{a}} \pm 0.77$ & $33.50^{\mathrm{a}} \pm 0.34$ & $34.2^{\mathrm{a}} \pm 1.32$ & $34.6^{\mathrm{a}} \pm 0.51$ & $36.2^{\mathrm{a}} \pm 0.63$ \\
\hline IMC+NS oil & $28.2^{\mathrm{a}} \pm 0.49$ & $30.75^{\mathrm{b}} \pm 0.30$ & $32.0^{\mathrm{b}} \pm 1.0$ & $33.0^{\mathrm{b}} \pm 0.57$ & $33.4^{\mathrm{c}} \pm 0.66$ \\
\hline
\end{tabular}

Values are expressed as means (5 mice \pm Standard Error (SE)

Values in the column with different letters are significantly different at $(\mathrm{p} \leq 0.01)$.

Zero: the day of application.

Table 2: Relative organs weight of male albino mice orally administrated with IMC (2.6 mg/kg bw), NS oil $(4 \mathrm{ml} / \mathrm{kg} \mathrm{bw})$ and their combination.

\begin{tabular}{|c|c|c|c|c|c|c|c|c|c|}
\hline \multirow{2}{*}{$\begin{array}{l}\text { Animal } \\
\text { Group }\end{array}$} & \multicolumn{3}{|c|}{ Liver } & \multicolumn{3}{|c|}{ Pancreas } & \multicolumn{3}{|c|}{ Kidney } \\
\hline & $\begin{array}{c}\text { Weight } \\
\text { (g) }\end{array}$ & $\begin{array}{c}\text { Relative } \\
\text { Weight } \\
(\%)\end{array}$ & $\begin{array}{c}\% \\
\text { Change }^{\mathrm{a}}\end{array}$ & $\begin{array}{c}\text { Weight } \\
\text { (g) }\end{array}$ & $\begin{array}{c}\text { Relative } \\
\text { Weight } \\
(\%) \\
\end{array}$ & $\begin{array}{c}\% \\
\text { Change }^{\mathrm{a}}\end{array}$ & $\begin{array}{c}\text { Weight } \\
\text { (g) }\end{array}$ & $\begin{array}{c}\text { Relative } \\
\text { Weight } \\
(\%)\end{array}$ & $\begin{array}{c}\% \\
\text { Change }^{\mathrm{a}}\end{array}$ \\
\hline $\mathrm{C}$ & $\begin{array}{l}1.7^{\mathrm{ab}} \\
\pm 0.06\end{array}$ & $\begin{array}{c}4.9^{\mathrm{a}} \\
\pm 0.06\end{array}$ & 0.0 & $\begin{array}{l}0.126^{\mathrm{a}} \\
\pm 0.003\end{array}$ & $\begin{array}{c}0.36^{\mathrm{a}} \\
\pm 0.008\end{array}$ & 0.0 & $\begin{array}{c}0.49^{\mathrm{a}} \\
\pm 0.003\end{array}$ & $\begin{array}{c}1.40^{\mathrm{a}} \\
\pm 0.012\end{array}$ & 0.0 \\
\hline NS oil & $\begin{array}{l}1.73^{\mathrm{ab}} \\
\pm 0.03\end{array}$ & $\begin{array}{c}4.8^{\mathrm{a}} \\
\pm 0.17\end{array}$ & -4.1 & $\begin{array}{l}0.128^{\mathrm{a}} \\
\pm 0.004\end{array}$ & $\begin{array}{c}0.38^{\mathrm{a}} \\
\pm 0.006\end{array}$ & -5.5 & $\begin{array}{c}0.47^{\mathrm{a}} \\
\pm 0.008\end{array}$ & $\begin{array}{l}1.39^{\mathrm{a}} \\
\pm 0.012\end{array}$ & 0.71 \\
\hline IMC & $\begin{array}{l}1.95^{\mathrm{b}} \\
\pm 0.03\end{array}$ & $\begin{array}{c}5.4^{\mathrm{c}} \\
\pm 0.12\end{array}$ & -10.2 & $\begin{array}{l}0.178^{\mathrm{c}} \\
\pm 0.001\end{array}$ & $\begin{array}{c}0.49^{\mathrm{c}} \\
\pm 0.017\end{array}$ & -36.1 & $\begin{array}{c}0.56^{\mathrm{b}} \\
\pm 0.006\end{array}$ & $\begin{array}{c}1.55^{\mathrm{c}} \\
\pm 0.001 \\
\end{array}$ & -10.7 \\
\hline $\begin{array}{l}\mathrm{IMC}+\mathrm{NS} \\
\text { oil }\end{array}$ & $\begin{array}{c}1.6^{\mathrm{a}} \\
\pm 0.06\end{array}$ & $\begin{array}{c}5.0^{\mathrm{b}} \\
\pm 0.23\end{array}$ & -2.0 & $\begin{array}{l}0.143^{\mathrm{b}} \\
\pm 0.002\end{array}$ & $\begin{array}{c}0.43^{\mathrm{b}} \\
\pm 0.012\end{array}$ & -19.4 & $\begin{array}{c}0.48^{\mathrm{a}} \\
\pm 0.006\end{array}$ & $\begin{array}{c}1.44^{\mathrm{b}} \\
\pm 0.004\end{array}$ & -2.9 \\
\hline
\end{tabular}

Values are expressed as means (5 mice) \pm Standard Error (SE)

Values in the column with different letters are significantly different at $(\mathrm{p} \leq 0.01)$.

a Percentage of increase (-) in treatment weights compared to control

Otherwise, Sellers et al., 2007 reported that changes in kidney weight may reflect renal toxicity, tubular hypertrophy or chronic progressive nephropathy.

\section{Biochemical studies}

The toxic effects of the repeated sublethal dose of IMC on the tested biochemical parameters in mice serum were illustrated in table 3 . The results in Table (3) showed significant $(\mathrm{p}<0.01)$ decrease in AST activity of IMC treated mice by about $70 \%$ from control, whereas a significant elevation in ALT activity by1.76 fold was observed. Morover alterations in AST and ALT activities were positively modulated by NS oil supplementation compared to control. Serum AST and ALT activities were believed to be a sensitive index for hepatocellular damage Peng et al., 2007. The liver dysfunction may be due to the changes in the liver enzyme activities, biosynthesis and altered membrane permeability permitting enzyme leakages into the blood Mansour and Mossa, 2010. Helling et al., 1995 ascertain that hepatic damage is considered pathologically irreversible, the ALT elevation may render the liver to be more susceptible to other pathogen/toxicants (Nayak et al., 1996 and Choudhary et al., 2003).

Table 3: Serum parameters of male albino mice orally administrated with IMC (2.6 mg/kg bw), NS oil $(4 \mathrm{ml} / \mathrm{kg} \mathrm{bw})$ and their combination.

\begin{tabular}{lcccccc}
\hline \multirow{2}{*}{ Animal Group } & \multicolumn{7}{c}{ Parameters (mean \pm SE; $\boldsymbol{n}=\mathbf{5})$} \\
\cline { 2 - 7 } & $\begin{array}{c}\mathbf{A S T} \\
\mathbf{( U / m l )}\end{array}$ & $\begin{array}{c}\text { ALT } \\
(\mathbf{U} / \mathbf{m l})\end{array}$ & $\begin{array}{c}\text { Glucose } \\
(\mathbf{m g} / \mathbf{d L})\end{array}$ & $\begin{array}{c}\boldsymbol{\alpha} \text {-Amylase } \\
(\mathbf{U} / \mathbf{L})\end{array}$ & $\begin{array}{c}\text { Urea } \\
(\mathbf{m g} / \mathbf{d l})\end{array}$ & $\begin{array}{c}\text { Creatinine } \\
(\mathbf{m g} / \mathbf{d l})\end{array}$ \\
\hline \multirow{2}{*}{$\mathrm{C}$} & $230^{\mathrm{c}}$ & $43^{\mathrm{a}}$ & $94^{\mathrm{a}}$ & $246^{\mathrm{c}}$ & $26^{\mathrm{a}}$ & $0.47^{\mathrm{a}}$ \\
& \pm 0.52 & \pm 0.50 & \pm 1.45 & \pm 0.67 & \pm 0.87 & \pm 0.006 \\
\hline \multirow{2}{*}{ NS oil } & $228^{\mathrm{c}}$ & $44^{\mathrm{a}}$ & $96^{\mathrm{a}}$ & $245^{\mathrm{c}}$ & $27^{\mathrm{a}}$ & $0.47^{\mathrm{a}}$ \\
& \pm 1.5 & \pm 0.45 & \pm 0.88 & \pm 2.3 & \pm 0.33 & \pm 0.003 \\
\hline \multirow{2}{*}{ IMC } & $69^{\mathrm{a}}$ & $76^{\mathrm{c}}$ & $215^{\mathrm{c}}$ & $183^{\mathrm{a}}$ & $35^{\mathrm{b}}$ & $2.5^{\mathrm{c}}$ \\
& \pm 0.57 & \pm 0.2 & \pm 1.44 & \pm 1.44 & \pm 0.58 & \pm 0.057 \\
\hline \multirow{2}{*}{ IMC+NS oil } & $105^{\mathrm{b}}$ & $52^{\mathrm{b}}$ & $102^{\mathrm{b}}$ & $211^{\mathrm{b}}$ & $28^{\mathrm{a}}$ & $0.95^{\mathrm{b}}$ \\
& \pm 1.7 & \pm 0.87 & \pm 1.50 & \pm 0.57 & \pm 0.50 & \pm 0.006 \\
\hline
\end{tabular}

Values in column with different letters are significantly different at $(\mathrm{p} \leq 0.01)$. 
$\alpha$-amylases, starch hydrolyzing enzymes, are synthesized by animals, plants, and microorganisms Tamura et al., 2007. Data in Table (3) show that $\alpha$ - amylase activity was significant ( $\mathrm{p}<$ 0.01 ) reduced under IMC toxication condition by $26.6 \%$ from control, whereas glucose level was significantly augmented by 2.28 fold compared to control. Co-administration of NS oil with IMC significantly modulated $(\mathrm{p}<0.01)$ the $\alpha$ - amylase activity and glucose level by 1.16 and 1.06 folds, respectively which close to control value. The significant decrease in amylase activity, which thought to be a consequence of IMC toxic effect, was in agreement with those reported by Shetti and Kaliwa, (2017). In contrast; some cells show increased catabolism to meet the energy demand under stress induced by the xenobiotics like pesticides (Ivanova-Chemishanska, 1982). The present data are in agreement with those of Kulkarni and Kaliwal, (2011) who reported an increase in amylase activity of immobilized and free Escherichia coli following monocrotophos and cypermethrin exposure.

Serum urea and creatinine levels usually used as clinical indicators of nephrotoxicity. Table (3) showed that IMC treatment caused a significant increase in urea and creatinine levels by 1.3 and 5.3 fold respectively, whereas NS oil co-administration greatly mitigate urea and creatinine levels near the control value. The deamination of amino acids in the liver produces urea which transported through the blood to the kidneys where it is excreted in urine (Harvey et al., 2011). In the present study, IMC exposed mice showing an elevation of serum urea which could be explained by 1) disturbance in protein metabolism, 2) impairment in its synthesis as a result of the impaired hepatic function and 3) decrease in the filtration rate of the kidney. In this context, Khan et al., 2008; Eissa and Zidan, 2009 documented that, pesticide exposure caused cytotoxic changes in the hepatic and renal biochemical markers which were positively correlated with the present data. The normal breakdown of muscle tissue produced creatinine, a waste product, which is normally filtered from the blood and excreted with urine. Also, Gowda et al., (2010) and Khan et al., (2012) revealed that the increase in creatinine level in response to IMC exposure indicates renal disease and may be a result of the impaired glomerular function.

The present data exhibited a significant elevation of total cholesterol, triglyceride and HDL levels in IMC treated mice by 2, 1.3 and 1.4 fold, respectively from control Table (4), and consequently increment in LDL and very lowdensity lipoprotein VLDL values, estimated according to Friedewald et al., (1972). Coadministration of NS oil with IMC significantly declined the IMC impact near to control value. The increase in cholesterol level may be a sign of liver damage which could be referred to; increased synthesis of cholesterol in the liver (Abdou and El Mazoudy 2010 and Padma et al., 2012), the effect of pesticides on the permeability of liver cell membrane (Kalender et al., 2005) and or the blockage of liver bile ducts causing reduction or cessation of its secretion to the duodenum (Aldana et al., 1998).

Table 4: Lipid profile of male albino mice orally administrated with IMC (2.6 mg/kg bw), NS oil (4 $\mathrm{ml} / \mathrm{kg} \mathrm{bw}$ ) and their combination.

\begin{tabular}{lccccc}
\hline \multirow{2}{*}{$\begin{array}{l}\text { Animal } \\
\text { Group }\end{array}$} & $\begin{array}{c}\text { TG } \\
\text { Triglycerides } \\
(\mathbf{m g} / \mathbf{d l})\end{array}$ & $\begin{array}{c}\text { Total } \\
\text { Cholesterol } \\
(\mathbf{m g} / \mathbf{d l})\end{array}$ & $\begin{array}{c}\text { HDL } \\
\text { Cholesterol } \\
(\mathbf{m g} / \mathbf{d l})\end{array}$ & $\begin{array}{c}\text { LDL } \\
\text { Cholesterol } \\
(\mathbf{m g} / \mathbf{d l})\end{array}$ & $\begin{array}{c}\text { VLDL } \\
\text { Cholesterol } \\
(\mathbf{m g} / \mathbf{d l})\end{array}$ \\
\hline \multirow{2}{*}{ C } & $151^{\mathrm{b}}$ & $97^{\mathrm{a}}$ & $70.6^{\mathrm{a}}$ & $-3.8^{\mathrm{c}}$ & $69.4^{\mathrm{a}}$ \\
& \pm 0.57 & \pm 0.58 & \pm 0.28 & \pm 0.03 & \pm 0.15 \\
\hline \multirow{2}{*}{ NS oil } & $147^{\mathrm{a}}$ & $101^{\mathrm{a}}$ & $71^{\mathrm{a}}$ & $0.6^{\mathrm{d}}$ & $67.6^{\mathrm{a}}$ \\
& \pm 0.88 & \pm 0.7 & \pm 1.15 & \pm 0.1 & \pm 0.4 \\
\hline \multirow{2}{*}{ IMC } & $204^{\mathrm{d}}$ & $197^{\mathrm{c}}$ & $99^{\mathrm{c}}$ & $57.2^{\mathrm{b}}$ & $93.8^{\mathrm{c}}$ \\
& \pm 0.57 & \pm 0.58 & \pm 0.86 & \pm 0.5 & \pm 0.53 \\
\hline \multirow{2}{*}{ IMC+NS oil } & $190^{\mathrm{c}}$ & $133^{\mathrm{b}}$ & $77^{\mathrm{b}}$ & $18^{\mathrm{a}}$ & $87.4^{\mathrm{b}}$ \\
& \pm 0.87 & \pm 1.4 & \pm 1.16 & \pm 0.4 & \pm 0.35 \\
\hline
\end{tabular}

Values in the column with different letters are significantly different at $(\mathrm{p} \leq 0.01)$.

LDL and VLDL were calculated according to Friedewald's equation 1972.

$\mathrm{LDL}=\mathrm{TC}-\mathrm{HDL}-\mathrm{TG} / 5 . \quad \mathrm{VLDL}=\mathrm{TG} / 2.175$.

TC: Total cholesterol, $\quad$ TG: Triglyceride

HDL: High-density lipoprotein cholesterol

LDL: Low-density lipoprotein cholesterol

VLDL: Very Low-density lipoprotein cholesterol. 


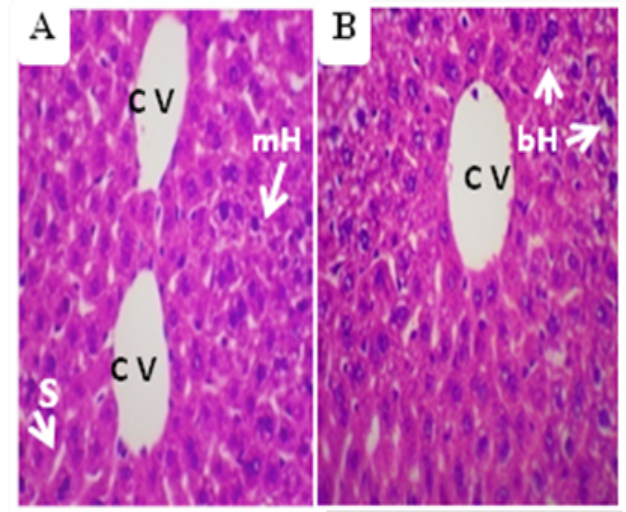

A \& B: liver section showing pathological free hepatic central vein $(\mathrm{CV})$, mono $(\mathrm{mH})$ and binucle ated (bH)hepatocytes and sinusoids (S) with normal architecture.

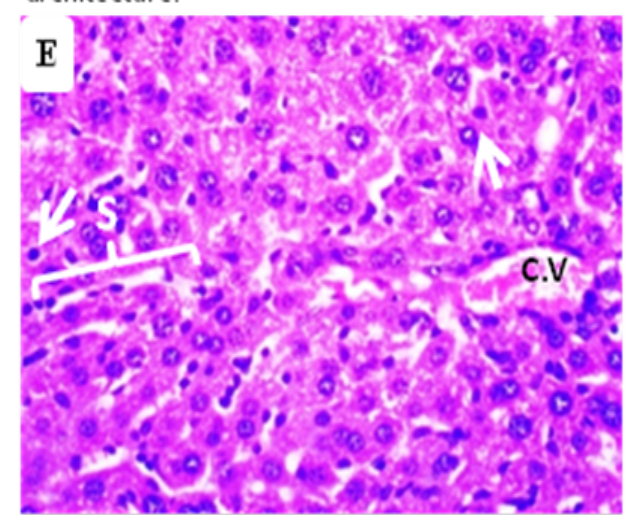

E: Liver section showing Necrosis, pyknotic cells (arrows), hemorrhage and central vein(CV) and sinusoids(S) dilation infiltration with redblood cells.

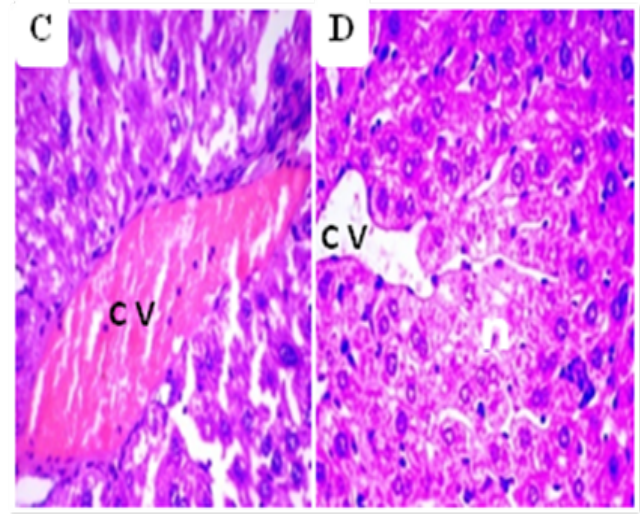

C \& D: liver section showing marked dilation and congestion of central vein, inflammation around it, pyknotic cell and necrosis(n).

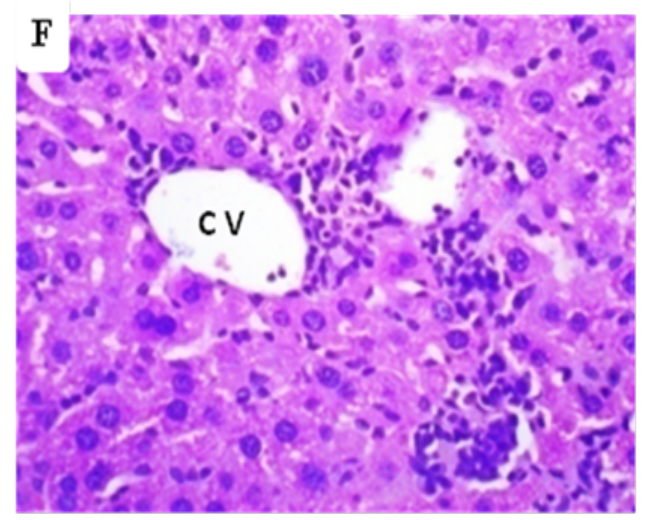

F: Liver section showing aggregation of inflammatory cell around central vein and pyknotic cells.

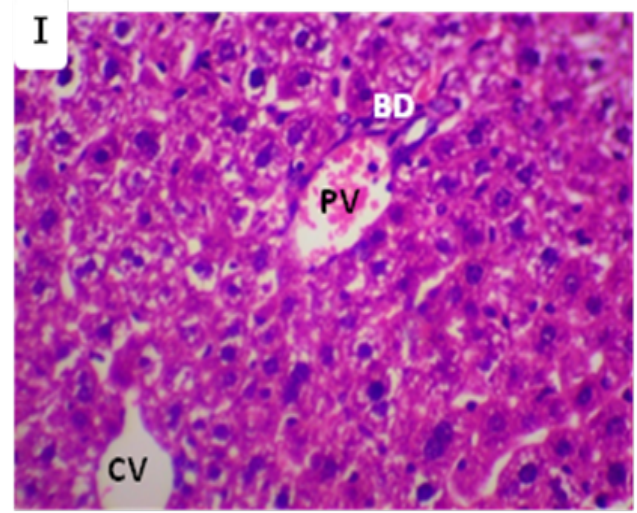

I: Liver section showing portal ve in (PV) and bile duct $(B D)$ with nominal histopathological changes denoting recovery.
G \& H: Liver section showing Portal tract surrounded by inflammatory cellular infiltration and cytoplasmic degeneration.

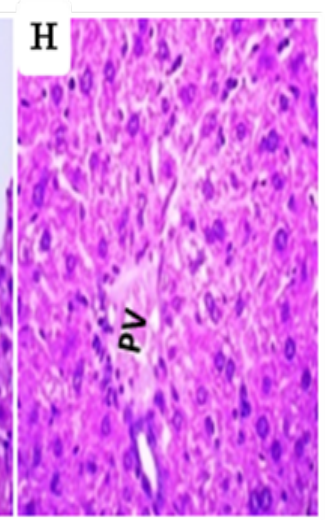

Fig. 1: Liver section showing many histological abnormalities of male albino mice orally administrated to IMC (2.6 mg/kg bw) (C- H), NS oil (4 ml/kg bw)(B) and their combination (I) comparing with control (A). (H \& E 400X). 


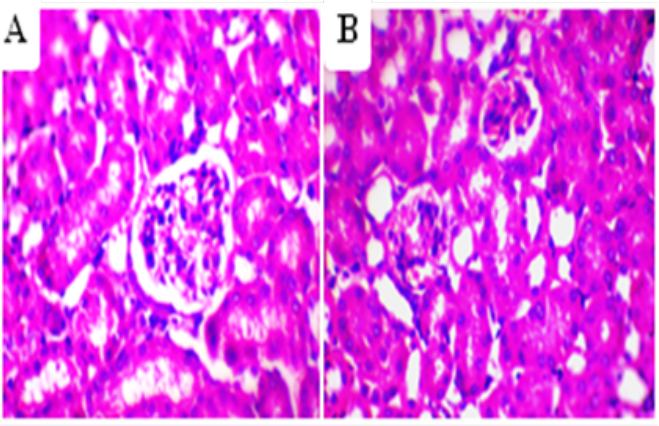

A \& B: Bowman's capsule), proximal tubules and urinary space with normal architecture.

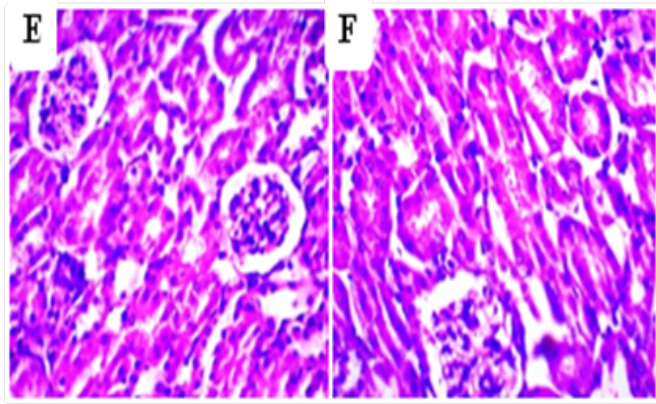

E: Necrosis, disturbed tubular epithelium and dilation in urinary space.

F: Hyperchromatic mesangial cells.

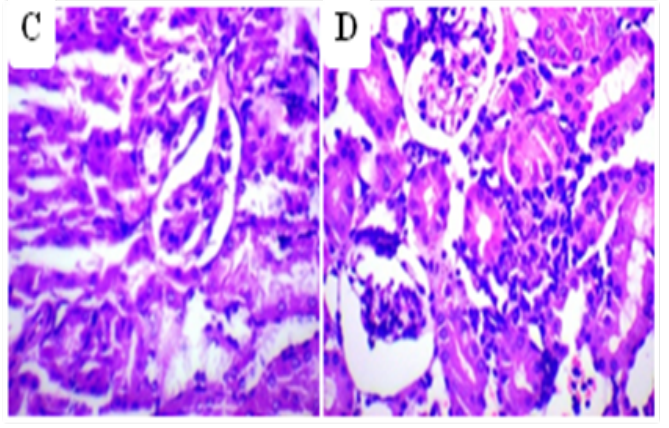

C: Congested de generative glomerulus, disturbed and necrotic tubular epithelia

D: Atrophied surrounded by inflammatory cells and dilated proximal tubules with disturbed epithelia.

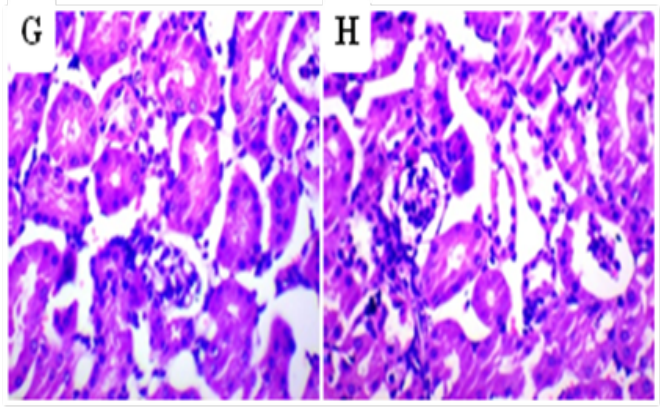

G \& H: Wide space of tubules with marked dilation atrophied (shranked Bowman's capsule).

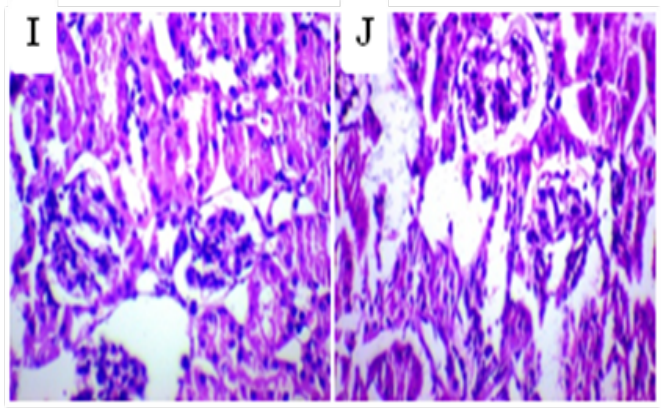

I \& J: Showing damage and disorganization of kidney tubules(lost architecture).

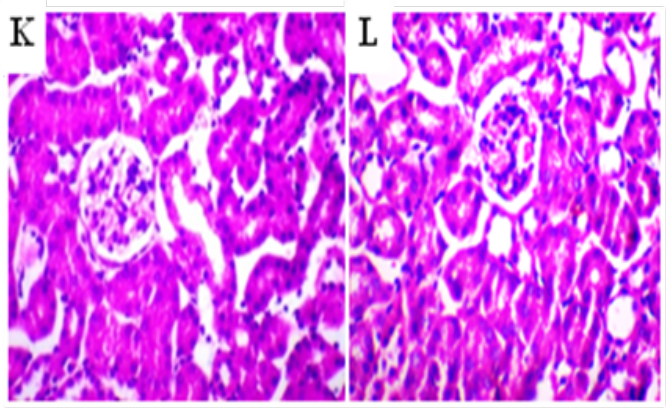

$\mathrm{K} \& \mathrm{~L}$ : intact capsule and normal arrangement of tubules in the cortical portion indicating recovery.

Fig. 2: Kidney section showing many histological abnormalities of male albino mice orally administrated to IMC $(2.6 \mathrm{mg} / \mathrm{kg}$ bw)(C- J), NS oil (4 ml/kg bw) (B) and their combination (K, L) comparing with control (A). (H \& E 400X). 
Ashgar et al., (1994) observed that methyl parathion elevate total cholesterol level in male rabbits, which is consistent with our findings. In contrary, Ananya et al., 2003 stated that some pesticides cause a decrease in total cholesterol level. Shakoori et al., (1988), documented that HDL-C is mainly synthesized in the liver and intestinal cells, it plays an important role in cholesterol efflux from tissues and return it to the liver for removal as bile acids. It has been established that the elevated serum or plasma HDL-C levels are antiatherogenic (McGill et al., 1981). Ryhanen et al., 1984 observed that serum HDL-C levels were increased in the dichlorvos treated rats which in consent with our results, whereas the HDL-C level reduction are associated with an increased risk for coronary artery disease (Stein 1987). Salem, (2005) and Saleem et al., (2012) mentioned that NS oil has hypoglycemic and nephroprotective effects, due to its ability to decrease hepatic gluconeogenesis as well as lowered serum creatinine and blood urea nitrogen values which consistent with the present findings.

\section{Histopathological examination}

histopathological assessments are regularly used for identifying organ abnormalities related to chemical exposure (Crissman et al., 2004). Fig. (1 A, B) illustrated the normal architecture and a pathological free mice liver section showing mono and binucleated hepatocytes with granular cytoplasm. Sinusoids (S) are evident between the cords of hepatocytes, Kupffer cells $(\mathrm{K})$ are associated with sinusoidal lining cells of liver control (A) and NS oil (B) groups. The IMC treated mice showed degenerative changes in the hepatocytes in the form of marked dilation, congestion, hemorrhage (Fig.1 C, D). Also, the results clarify infiltration with red blood cells, pyknotic cell, necrosis (E) and hepatic aggregation of the inflammatory cell around central vein $(F)$ while portal inflammation and cytoplasmic degeneration were represented in (Fig. $1 \mathrm{G}, \mathrm{H}$ ).

The observation in this study are in agreement with those of Choudhary et al., (2003) who revealed that endosulfan treated rats exhibited liver degenerative changes include binucleated cells, hypertrophy of hepatocytes, lymphocytic infiltration in the central vein and dilation of sinusoidal spaces with the irregular nuclear shape. Also, Kostka et al., (2000) detected that in rats, treated with permethrin and DDT separately; liver section of permethrin treated rats presented, pyknotic nuclei, acidophilic cytoplasm, and cell with nuclear fragmentation, whereas DDT causes cytoplasmic vacuolization and hepatocyte necrosis and all the previous mentioned symptoms are in line with our findings. At the present work co-administration of NS oil implies that hepatocytes, central vein, portal vein (PV) and bile duct (BD) showing nominal histological changes attending recovery (Fig. 1 I), meaning that NS oil lightened the lesions caused by IMC treatment in mice, this data is in concomitant with, Kapoor, (2009).

Fig. (2). represent kidney sections from the control group (A) and NS oil-treated mice (B) showed intact histological structure of glomeruli and renal tubules. However, abnormalities in kidney of treated mice were detected in glomeruli and in convoluted tubules (Figure 2C-J). The main characteristic findings were the appearance of; congested degenerative glomerular tuft, disturbed and necrotic tubular epithelia, dilated atrophied, infiltration in between the degenerated tubules with fibrosis and hyalinosis between the tubules in a focal manner, wide space dilated proximal tubules, hyperchromatic mesangial cells, shrunken Bowman's capsule, damage and disorganization of kidney tubules (lost architecture) were also observed. The present findings of mice kidney tissues treated with IMC revealed histological changes, similar signs of toxicity were also reported earlier by Kammon et al., 2010 and Marrs 2012. Co-administration of the NS oil with IMC showed marked improvement in kidney histological structure compares to the IMC group alone (Fig. 2 K, L). Khajavi rad et al., 2008 and Mohammadian et al., (2008) indicated that NS oil has significant preventive and disruptive effects against renal calculi and $\mathrm{CaOx}$ deposits and that in line with our present data.

\section{CONCLUSION}

The present study concluded that IMC at the sublethal dose, $2.6 \mathrm{mg} / \mathrm{kg}$ bw, induced cytotoxic changes in the liver, pancreas, and kidney as manifested by biochemical results and histopathological findings, NS oil attenuates the IMC adverse effects, due to antioxidant and cytoprotective property, so we highlight its use as a food supplement.

\section{REFERENCES}

Adams, S M, (2002). Biological indicators of aquatic ecosystem stress. Am. Fish. Soc., 3: 104-112.

Abdou, H M, and El Mazoudy, R H (2010). Oxidative damage, hyperlipidemia and histological alterations of cardiac and skeletal muscles induced by different doses of diazinon in female rats. J. Hazard. Mater. 182 (1-3), 273-278.

Aldana, L, de Mejía EG, Craigmill A, Tsutsumi V, Armendariz-Borunda J, Panduro $\mathrm{A}$ and Rincón AR (1998). Cypermethrin increases apo A-1 and apo B mRNA but not hyperlipidemia in rats. Toxicol. Lett. 95: 31-9. 
Ananya, RS, Subeena DA, Kumar DT and Kumar MS (2003). Oxidative stress and histopathological changes in the heart following oral lindane (gamma exachloroh hexane) administration in rats. Med. Sci. Monit. 11: 325-9.

Arafa UA, Fujiwara Y, Higuchi K, Shiba M, Uchida $\mathrm{T}$, Watanabe $\mathrm{T}$, Tominaga $\mathrm{K}$, Oshitani $\mathrm{N}$, Matsumoto T, Arakawa T (2003). No additive effect between Helicobacter pylori infection and portal hypertensive gastropathy on inducible nitric oxide synthase expression in gastric mucosa of cirrhotic patients. Dig Dis Sci. 48(1): 162-8.

Arumugam G, Manjula $P$ and Paari N (2013). A review: Anti diabetic medicinal plants used for diabetes mellitus. J. Acute Dis. 2(3): 196-200.

Pallavi B, Chandresh V, Kanika K, Tammana T (2015). In vitro evaluation of antidiabetic and antioxidant activity of Seabuckthorn (Hippophae rhamnoides L.). J Med Plants Res. 9(35): 929-32.

Ashgar, M, Sheikh MA and Hashmi A (1994). Effects of orally fed methyl parathion on some hematochemical parameters of rabbits. Pakistan Vet. J. 14: 34-6.

Bhatnagar, P and Jain N (1986). Morphofunctional changes in the liver of male mice after chronic treatment with phosphamidon. Bull. Environ. Contam. Toxicol. 37: $767-773$.

Choudhary, N, Sharma M, Verma P and Joshi S C (2003). Hepato and nephrotoxicity in rat exposed to endosulfan. J. Environ. Biol. 24, 305-308.

CoStat program version 6.2; cohort software: Tucson, AZ, 2002.

Crissman, JW, Goodman DG, Hildebrandt PK, Maronpot RR, Prater DA, Riley, JH, Seaman WJ and Thake, DC (2004). Best practice guideline: Toxicologic histopathology. Toxicol. Pathol, 32: 126-131.

Drury, R A B and Wallington E A (1980). Carleton's histological technique. $5^{\text {th }}$ ed. Oxford, NY. University Press, pp: 241-243.

Eissa, F I, and Zidan N A (2009). Hematological, biochemical and histopathological alterations induced by abamectin and Bacillus thuringiensis in male albino rats. Australian J. Basic and Applied Sci. 3: 2497-2505.

Fassati, P. and Prencipe, L. (1982). Serum triglycerides determined colorimetrically with an enzyme that produces hydrogen peroxide. Clin. Chem.28: 2077-2080.

Fawcett, J.K .and Scott, J.E. (1960). Determination of urea (urease modified Berthelot reaction). J. Clin. Pathol. 13 (2): 156-159.
Friedewald, WT, Levy RI and Fredrickson DS (1972). Estimation of the concentration of low-density lipoprotein cholesterol in plasma, without the use of the preparative ultracentrifuge. Clin. Chem. 18: 499-502.

Gowda S, Desai PB, Kulkarni SS, Hull VV, Math AAK and Vernekar SN (2010). Markers of renal function tests. North Am. J. Med. Sci. 2: 170-173.

Grove TH. (1979). Effect of reagent $\mathrm{pH}$ on the determination of high-density lipoprotein cholesterol by precipitation with sodium phosphotungstate-magnesium. Clin Chem. 25: 560-564

Gupta, RC, Goad, JT, Kadel, WL (1994). In vivo acute effects of carbofuran on protein lipid and lipoproteins in rat liver and serum. J. Toxicol. Environ. Health. 42: 451-62.

Harvey, RA, Ferrier DR and Lippincott's (2011). Illustrated Reviews: Biochemistry. 5th ed. Philadelphia, PA, USA: Lippincott Williams and Wilkins, a Wolters Kluwer business.

Helling, TS, Wogahn BM, Olson S A, Evans L S, Reddy B R and VanWay C (1995). The effect of prostaglandin $\mathrm{E} 1$ on liver adenine nucleotides and cytoplasmic enzymes in a porcine model of normothermic hepatic ischemia. Hepatology, 22: 1554-1559.

Ivanova-Chemishanska, L, (1982). Dithiocarbamates, WHO Copenhagen, Interim Document, 29: 158-169.

Jaffé, M (1886). Ueber den Niederschlag welchen Pikrinsäure in normalen Harn erzeugt und über eine neue reaction des Kreatinins. Z. Physiol Chem. 10: 391-400.

Kalender, S, Ogutcu A, Uzunhisarcikli M, Açikgoz F, Durak D, Ulusoy $\mathrm{Y}$ and Kalender Y (2005). Diazinon-induced hepatotoxicity and protective effect of vitamin $\mathrm{E}$ on some biochemical indices and ultrastructural changes. Toxicology, 211: 197-206.

Kammon, A M, Brar R S, Banga H S and Sodhi S (2010). Patho-biochemical studies on hepatotoxicity and nephrotoxicity on exposure to chlorpyrifos and imidacloprid in layer chickens. Vet. Arch. 80: 663-672.

Kannel, W B, Casteli W B and Gordon T L (1979). Cholesterol in the prediction of atherosclerotic disease. New perspectives based on the Framingham study. Ann. Intern. Me. 90: 85-91.

Kapoor, S (2009). Emerging clinical and therapeutic applications of Nigella sativa in gastroenterology. World J Gastroenterol. 7: 2170-2171. 
Khajavi rad A, Hadjzadeh MR and Monavvar N (2008). Preventive effects of ethyl acetate fractions from the aqueous and ethanolic extract of Nigella sativa L. seeds on calcium oxalate kidney stones in Wistar rats. Koomesh, 9: $123-132$.

Khan DA, Bhatti MM, Khan FA, Naqvi ST and Karam A (2008). Adverse effects of pesticides residues on biochemical markers in Pakistani tobacco farmers. Int. J. Clin. Exp. Med. 1: 274-282.

Khan, AL, Ahmad L and Khan MZ (2012). Hematobiochemical changes induced by pyrethroid insecticides in avian, fish and mammalian species. Int. J. Agric. Biol. 14: 834-842.

Kidd, H and James D R (1991). The Agrochemicals Handbook, Royal Society of Chemistry, Cambridge.

Kostka, G, Palut D, Kopec-Szlezak J and Kudwicki $\mathrm{J} K$ (2000). Early hepatic changes in rats induced by permethrin in comparison with DDT. Toxicol. 142, 135-143.

Kulkarni AG and Kaliwal BB (2011). Effect of methomyl on protease activity in free and immobilized Escherichia Coli. Int. J. Microbiol. Res. 3: 74-78.

Kurrle-Weitenhiller A, Hölzel W, Engel D, Finke, J, and Klein, G. (1996). Method for the determination of total and pancreatic $\alpha$ amylase based on $100 \%$ cleavage of the protected substrate ethylidene-4-nitrophenylmaltoheptaose. Clin. Chem. 42 (6): 14-14.

Lee Chao, S and Casida, JE (1997) Interaction of imidacloprid metabolites and analogs with the nicotinic acetylcholine receptor of mouse brain in relation to toxicity, Pestic. Biochem. Physiol. 58: 77-88.

Mansour, SA and Mossa A H (2010). Oxidative damage, biochemical and histopathological alteration in rat exposed to chlorpyrifos and the role of zinc as the antioxidant. Pest. Biochem. Physiol. 96: 14-23.

Marrs, T C (2012). Royal Society of Chemistry; Mammalian Toxicology of Insecticides.

McGill, HC, Jr, McMahan, CA, Kruski AW and Mott GE (1981). Relationship of lipoprotein cholesterol concentrations to experimental atherosclerosis in baboons. Arteriosclerosis, 1: 3-12

Meister, R (1995). Farm chemical handbook '95. Meister Publishing Company. Willoughby, $\mathrm{OH}$

Mela, M, Randi M A F, Ventura D F, Carvalho C E $\mathrm{V}$, Pelletier $\mathrm{E}$ and Oliveira C A, Ribeiro, (2007). Effects of dietary methylmercury on liver and kidney histology in the neotropical fish Hoplias malabaricus. Ecotoxicol. and Environ. Saf. 68: 426-435.
Mohammadian, N, Rahmani Z and Rassouli FB (2008). Effect of thymoquinone on ethylene glycol-induced kidney calculi in rats. Urology J. 5(3), 149-155.

Narra, MR (2016). Single and cartel effect of pesticides on the biochemical and hematological status of Clarias batrachus: A long-term monitoring. Chemosphere. 144: 966-74.

Narra, MR (2017). Hematological and immune upshots in Clarias batrachus exposed to dimethoate and defying response of dietary ascorbic acid. Chemosphere. 168: 988-95.

Nayak, N C, Sathar S A, Mughal S, Duttagupta S, Mathur M and Chopra P (1996). The nature and significance of liver cell vacuolation following hepatocellular injury-an analysis based on observations on rats rendered tolerant to hepatotoxic damage. Virchows Archiv. 428: 353-365.

Okuna, K T, Kohdo H and Mtyamoto J (1976). Mammalians toxicological study of permethrin, 3 phenoxy benzyl $( \pm)$ trans $-2,2-$ dimethyl-3-(2, 2 dichlorvinyl) - cyclopropane -1-carboxylate. Botyukgoku. 41: 143-151.

Organization for Economic Cooperation and Development, OECD (2008). Guidelines for the testing of chemicals/draft updated test guideline: Repeated dose 28-day oral toxicity study in rodents: 407.

Padma, V V, Lalitha G, Shirony N P and Baskaran R (2012). Effect of quercetin against lindane induced alterations in the serum and hepatic tissue lipids in Wistar rats. Asian Pac. J. Trop. Biomed. 2: 910-915.

Palanivelu, C, Jani, K, Malladi, V, Senthilkumar, R, Rajan, P S, Sendhilkumar, K and Kavalakat, A (2006). Laparoscopic management of hepatic hydatid disease. JSLS. 10(1): 56-62.

Peng, D, Chen S, Ruan L, Li L, Yu Z and Sun M (2007). Safety assessment of transgenic Bacillus thuringiensis with VIP insecticidal protein gene by feeding studies. Food Chem. Toxicol. 45: 1179-1185.

Piñeiro-Carrero VM, Piñeiro EO (2004). Liver. Pediatrics; 113(4 Suppl): 1097-106

Plaa, G L (1980). Toxic responses of the liver. In: Casarett and Doull's toxicology: The basic science of poisons. $2^{\text {nd }}$ ed., J. Doull, C.D. Klaassen, and M.O. Amdur (Eds.). Macmillan, New York.

Powers, AC (2011). Diabetes mellitus. In: Longo DL, Fauci AS, Kasper DL, Hauser SL, Jameson JL, Loscalzo J. Harrison's principles of internal medicine. $18^{\text {th }}$. ed. New York: McGraw Hill Medical; p.2968-3003.

Price, C, Finney, H (2000). Developments in the assessment of glomerular filtration rate. Clinica. Chimica. Acta. 29 (1-2): 55-66. 
Randhawa, M A (2008). An update on antimicrobial effects of Nigella sativa and experience at King Faisal University, Dammam, Saudi Arabia. JSSDDS, 12 (1), 36-43.

Randhawa, MA, and Alghamdi MS (2011). Anticancer activity of Nigella sativa (Black Seed) a review. Am. J. Chin. Med. 39 (6), 1075 - 1091.

Randhawa, MA, and Alghamdi, MS (2002). A review of the pharmacotherapeutic effects of Nigella sativa. Pak. J. Med. Res. 41 (2), $77-$ 83.

Reitman, S. and Frankel, S. A. (1957). Colorimetric method for the determination of serum glutamic oxalacetic and glutamic pyruvic transaminases. Am. J. Clin. Path. 28 (1): 5660.

Rej, R (1989). Aminotransferases in disease. Clin. Lab. Med. 9(4): 667-87.

Richmond, W. (1973). Preparation and properties of a cholesterol oxidase from Nocardia sp. and its application to the enzymatic assay of total cholesterol in serum. Clin. Chem. 19: 13501356.

Robinson, K M and Yarbrough J D (1978). Liver response to oral administration of Mirex in rates. Pest. Biochem. Physiol. 8: 65-72.

Ryhanen, R, Herranen J, Karhonen K, Penttila I, Popvilanpi $M$ and Puhakainen E (1984). The relationship between serum lipids, lipoproteins and pseudocholinesterase during organophosphate poisoning in rabbits. Int. J. Biochem. 16: 687-90.

Saleem, U, Ahmad B, Rehman K, Mahmood S, Alam $M$ and Erum A (2012). Nephroprotective effect of vitamin C and Nigella sativa oil on gentamicin associated nephrotoxicity in rabbits. Pakestan J. Pharm. Sci. 25: 727-730.

Salem, M L (2005). Immunomodulatory and therapeutic properties of Nigella sativa L. seed. Int. Immunopharmacol. 5: 1749-1770.

Sellers, RS, Morton D, Michael B, Roome N, Johnson JK and Yano B L (2007). Society of toxicological pathology position paper: Organ weight recommendations for toxicology studies. Toxicol. Pathol. 35: 751-755.

Shakoori, AR, Ali S S and Saleem M A (1988). Effects of six months feeding of cypermethrin on the blood and liver of albino rats. J. Biochem. Toxicol. 3: 59-72.

Shetti, AA and Kaliwa BB (2017). Impact of imidacloprid intoxication on amylase and protease activity in soil isolate Escherichia coli, J. Chem. and Pharmacol. Res. 9:13-17.
Simons, J E, Yany R S and Berman F (1995). Evaluation of the nephrotoxicity of a complex mixture containing organics and metals. Advantages and disadvantages of the use of real-world complex mixture. Environ. Health Prospect.103: 67-71.

Slotkin, TA, Brown, KK, Seidler, FJ (2005). Developmental Exposure of Rats to Chlorpyrifos Elicits Sex-Selective Hyperlipidemia and Hyperinsulinemia in Adulthood. Environ. Health .Perspect. 113(10): 1291-4.

Stein, E A (1987). Lipids, lipoproteins, and apolipoproteins; in Fundamentals of Clinical Chemistry, Tietz, N. W. (ed.), 3rd ed., W. B. Saunders Company. Philadelphia, USA.

Tamura, K, Dudley J and S Kumar M Nei (2007). Molecular evolutionary genetics analysis (MEGA), software version 4.0, Mol. Biol. Evol. 24: 1596-1599.

Tomizawa M, Lee DL and Casida JE, (2005). Neonicotinoid insecticide toxicology: Mechanisms of selective action, Ann. Rev. Pharmacol. Toxicol. 45: 247.

Tomizawa, M and Yamamoto I (1993). Structureactivity relationships of nicotinoids and imidacloprid analogs. J. Pest. Sci. 18: 91-98.

Trinder, $\mathrm{P},(\mathbf{1 9 6 9})$. Determination of glucose in blood using glucose oxidase with an alternative oxygen receptor. Ann. Clin. Biochem. 6: 2427.

Ware GW and Whitacre DM, (2004). An introduction to insecticides, fourth ed., Meister Pro Information Resources, A division of Meister Media Worldwide, Willoughby, Ohio, USA.

William, J, Meggs MD, PhDa, Kori L, Brewer, PhDa (2007). Weight gain associated with chronic exposure to chlorpyrifos in rats, J. Med. Toxicol. 3: 89-93.

World Health Organization, WHO (2004). Toxicological evaluations: Imidacloprid; Int. Program. On Chem. Saf.

World Health Organization, WHO (2005). The WHO Recommended classification of pesticides by hazard and guidelines to classification. Corrigenda published by April 12, 2005 incorporated. IPCS, Geneva 2004.

Wroblewski, $\mathrm{F}(\mathbf{1 9 5 8})$. The clinical significance of alterations in transaminase activities of serum and other body fluids. Adv. Clin. Chem. 1(2): 313-51. 


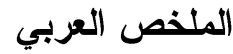

\section{تأثير زيت حبة البركة Nigella sativa على السمية المستحثة بمبيد الإيميداكلوبريد}

\author{
فى ذكور الفئران البيضاء \\ رضا خميس عبد الرازق على \\ قسم بحوث سمية المبيدات للثدييات ـ المعمل المركزى للمبيدات - مركز البحوث الزر اعية - الاسكندرية
}

الإيميداكلوبريد (IMC) هو مبيد حشر ات جهــازى يـستخدم علــى نطــاق و اســـع فـي كـلـ مــن الزر اعــة

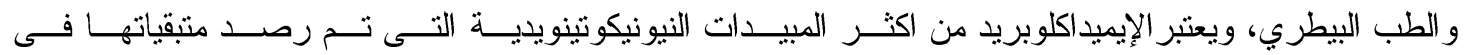

الفو اكه و الخضروات، لذا وضعت هذه الدر اســـة لتقبــيم التغيــرات البيوكيميائيــة و النــسيجية المرتبطـــة بـسمية

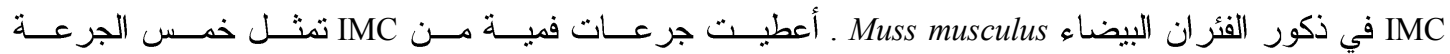

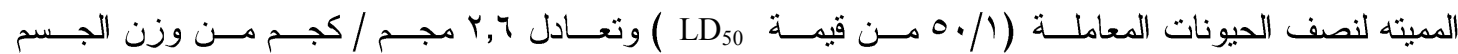

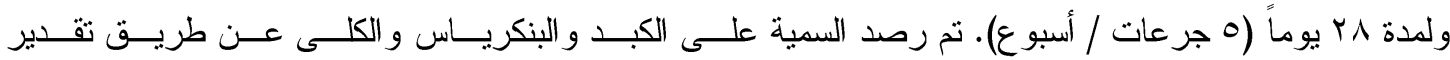

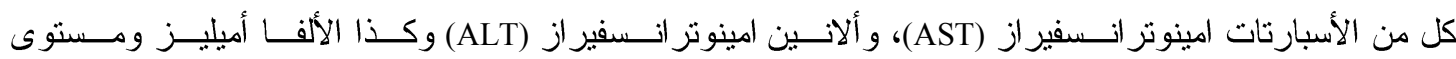

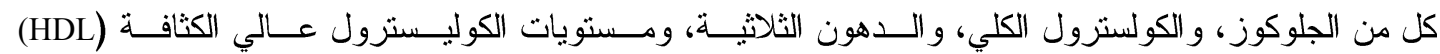

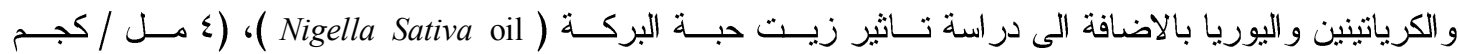

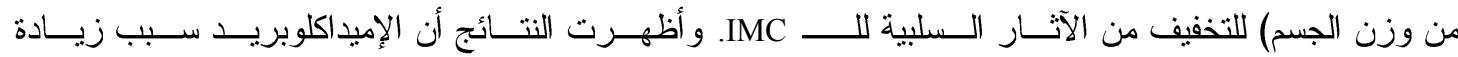

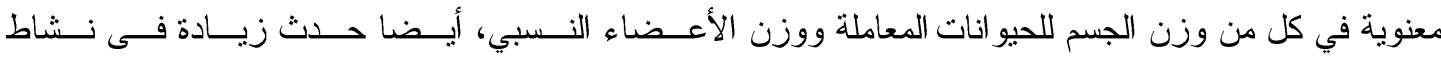

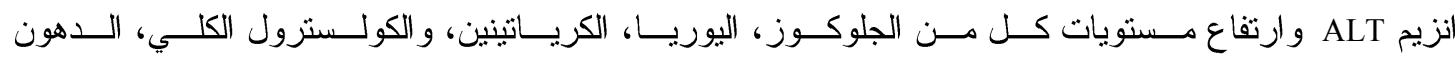

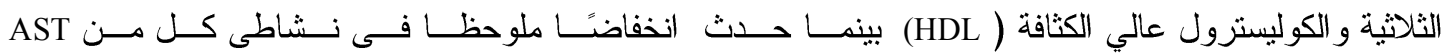

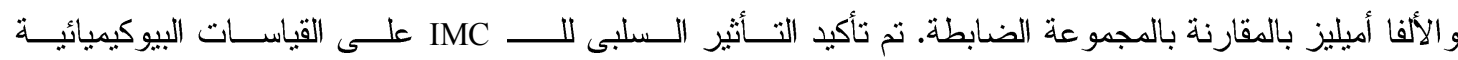

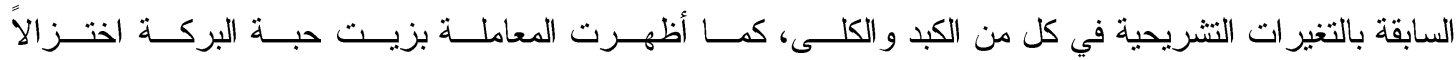

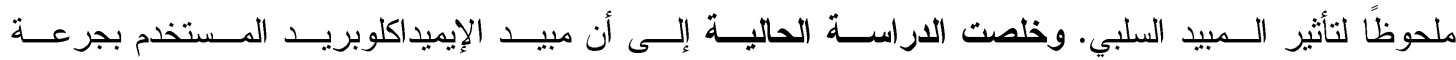

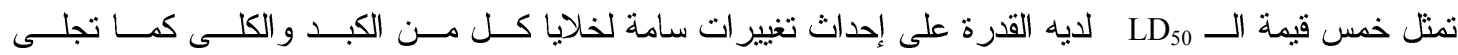

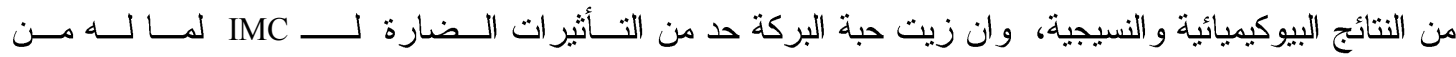
خصائص مضادة للاكسدة وحامية للانسجة. 